\title{
REDUCTION OF COD IN WASTEWATER FROM A TEXTILE INDUSTRY BY ELECTRO-FENTON PROCESS
}

APAYDIN Ö.
Yildiz Technical University

Civil Engineering Faculty, Environmental Engineering Department

Istanbul, TURKEY
Received: $10 / 12 / 2013$

Accepted: $10 / 06 / 2014$

Available online: 13/06/2014 *to whom all correspondence should be addressed: e-mail: apaydin@yildiz.edu.tr

\section{ABSTRACT}

Advanced oxidation processes (AOPs) have led the way in the treatment of aqueous waste and are rapidly becoming the chosen technology for many applications. In this paper, COD reduction of textile industry wastewater by electro-Fenton (EF) oxidation, was studied at batch experimental conditions. The wastewater samples with a COD of $590 \mathrm{mg} \mathrm{I}^{-1}$ in average were taken from the outlet of an equalization tank of a textile industry in the Marmara Region in Turkey. The wastewater samples were treated in a batch reactor equipped with two iron electrodes. The EF tests were conducted at different $\mathrm{H}_{2} \mathrm{O}_{2}$ doses such as $313,626,940$, and $1253 \mathrm{mg} \mathrm{l}^{-1}$ and constant electrical power of $24 \mathrm{~W}$ and pH of 3 . For each EF test electricity consumption was determined based on per unit of COD mass removed $\left(\mathrm{kW} \mathrm{kg}{ }^{-1}\right)$. The COD removal increased with decreasing $\mathrm{H}_{2} \mathrm{O}_{2}$ dose. The highest treatment efficiency was attained at $313 \mathrm{mg} \mathrm{l}^{-1}$ of $\mathrm{H}_{2} \mathrm{O}_{2}$, by which more than $85 \%$ of COD was removed within 10 min of reaction time. These results indicate that the EF process can be considered as an alternative method for textile wastewater treatment.

Keywords: Advanced oxidation processes, COD removal; electro-Fenton process, iron electrodes, textile wastewater.

\section{Introduction}

Mechanism for decomposition of $\mathrm{H}_{2} \mathrm{O}_{2}$ in acidic solution in dark and in the absence of organic compounds consists of the sequence of reactions [1-8] (Pignatello et al., 2006). Among these reactions, the production of hydroxyl radicals occurs in the cycle of $\mathrm{Fe}^{3+}$ to $\mathrm{Fe}^{2+}$ and the quenching of $\bullet \mathrm{OH}$ by $\mathrm{Fe}^{2+}$ and $\mathrm{H}_{2} \mathrm{O}_{2}$.

$$
\begin{aligned}
& \mathrm{Fe}^{2+}+\mathrm{H}_{2} \mathrm{O}_{2} \rightarrow \mathrm{Fe}^{3+}+\mathrm{OH}^{-} \cdot \bullet \mathrm{OH} \\
& \mathrm{Fe}^{3+}+\mathrm{H}_{2} \mathrm{O}_{2} \rightarrow \mathrm{Fe}^{2+}+\mathrm{H}^{+}+\mathrm{HO}_{2} \bullet \\
& \bullet \mathrm{OH}+\mathrm{H}_{2} \mathrm{O}_{2} \rightarrow \mathrm{HO}_{2} \bullet+\mathrm{H}_{2} \mathrm{O} \\
& \bullet \mathrm{OH}+\mathrm{Fe}^{2+} \rightarrow \mathrm{Fe}^{3+}+\mathrm{OH}^{-} \\
& \mathrm{Fe}^{3+}+\mathrm{HO}_{2} \bullet \rightarrow \mathrm{Fe}^{2+}+\mathrm{H}^{+}+\mathrm{O}_{2} \\
& \mathrm{HO}_{2} \bullet+\mathrm{Fe}^{2+}+\mathrm{H}^{+} \rightarrow \mathrm{Fe}^{3+}+\mathrm{HO}_{2}^{-} \\
& 2 \mathrm{HO}_{2} \bullet \rightarrow \mathrm{H}_{2} \mathrm{O}_{2}+\mathrm{O}_{2} \\
& 2 \mathrm{H}_{2} \mathrm{O}_{2} \rightarrow \mathrm{O}_{2}+2 \mathrm{H}_{2} \mathrm{O}
\end{aligned}
$$


An increase in $\mathrm{H}_{2} \mathrm{O}_{2}$ dose usually results with an increase in the formation of hydroxyl radicals, but at somewhere it reaches to an optimum value, above which the $\bullet \mathrm{OH}$ generation does not change significantly. If $\mathrm{H}_{2} \mathrm{O}_{2}$ is used in excessive amounts, $\bullet \mathrm{OH}$ radical generation might be lowered due to the formation of less reactive radicals such as $\mathrm{HO}_{2}{ }^{\circ}$, as shown by the reactions 2 and 3 , and therefore Fenton oxidation becomes less effective for the treatment organic or inorganic compounds. Oxidation potentials of hydroperoxyl radicals (1.25 volt) are lower than $\mathrm{H}_{2} \mathrm{O}_{2}$ (1.31 volt) (Parsons, 2004).

Table 1. Unit energy demand for pollutant removal in wastewater treatment by electro-chemical process

\begin{tabular}{|c|c|c|c|c|c|}
\hline Wastewater type & Process & $\begin{array}{l}\text { Reaction } \\
\text { time, hour } \\
\text { (min) }\end{array}$ & $\begin{array}{l}\text { UED, } \mathrm{kWh} \mathrm{kg}^{-1} \\
\text { pollutant }^{-1} \\
\text { removed }^{-1}\end{array}$ & $\begin{array}{l}\text { Pollutant } \\
\text { (removal) }\end{array}$ & Reference \\
\hline $\begin{array}{c}\text { Textile } \\
\text { wastewater }\end{array}$ & $\begin{array}{c}\text { Electro-chemical } \\
\text { Anode: Iron } \\
\text { Cathode: Iron }\end{array}$ & $0.17(10)$ & 0.008 & COD (86 \%) & (Current study) \\
\hline \multirow{2}{*}{ Textile dyeing } & Electro-coagulation & - & 4.7 & Dye (75 \%) & \multirow{2}{*}{ (Daneshvar et al., 2006) } \\
\hline & $\begin{array}{l}\text { Anode: Iron } \\
\text { Cathode: Steel } \\
\end{array}$ & - & 7.57 & Dye (98\%) & \\
\hline \multirow[b]{2}{*}{$\begin{array}{c}\text { Dyeing } \\
\text { wastewater }\end{array}$} & Electro-coagulation & & 15.0 & COD (90\%) & \multirow[b]{2}{*}{ (Chen et al., 2003) } \\
\hline & $\begin{array}{l}\text { Anode: Boron-doped } \\
\text { diamond (BDD) } \\
\text { Cathode: Stainless } \\
\text { steel (SS) }\end{array}$ & - & 20.1 & COD (89\%) & \\
\hline $\begin{array}{c}\text { Dyeing } \\
\text { wastewater }\end{array}$ & $\begin{array}{c}\text { Electro-coagulation } \\
\text { Anode and Cathode: } \\
\text { Mild Steel }\end{array}$ & - & 50 & COD (98\%) & (Golder et al., 2005) \\
\hline $\begin{array}{c}\text { Tannery } \\
\text { wastewater }\end{array}$ & $\begin{array}{c}\text { Electro-chemical } \\
\text { Anode: Iron } \\
\text { Cathode: Iron } \\
\end{array}$ & $0.17(10)$ & 3.1 & COD (72 \%) & (Kurt et al., 2007) \\
\hline $\begin{array}{c}\text { Domestic } \\
\text { wastewater }\end{array}$ & $\begin{array}{c}\text { Electro-chemical } \\
\text { Anode: Ti/Pt, } \\
\text { Cathode: SS } 304 \\
\end{array}$ & $1(60)$ & 12.4 & COD (89 \%) & (Vlyssides et al., 2002) \\
\hline $\begin{array}{c}\text { Methylene } \\
\text { parathion } \\
\text { pesticide in } \\
\text { aqueous solution }\end{array}$ & $\begin{array}{l}\text { Electro-chemical } \\
\text { Anode: } \mathrm{Pt} / \mathrm{Ti}, \\
\text { Cathode: } \mathrm{SS} 304\end{array}$ & $2(120)$ & $8-18$ & $\operatorname{COD}(80 \%)$ & (Arapoglou et al., 2003) \\
\hline \multirow{2}{*}{$\begin{array}{c}\text { Synthetic } \\
\text { wastewater }\end{array}$} & $\begin{array}{c}\text { Electro-chemical } \\
\text { Anode and Cathode: }\end{array}$ & -- & 1880 & $\begin{array}{l}\text { Phenol } \\
(99.7 \%)\end{array}$ & \multirow{3}{*}{$\begin{array}{l}\text { (Yavuz and Koparal, } \\
\text { 2006) }\end{array}$} \\
\hline & RuO2 & & 2112 & $\operatorname{COD}(88.9 \%)$ & \\
\hline $\begin{array}{l}\text { Petroleum } \\
\text { refinery } \\
\text { wastewater }\end{array}$ & $\begin{array}{c}\text { Electro-chemical } \\
\text { Anode and Cathode: } \\
\text { RuO2 }\end{array}$ & - & - & COD (70.1\%) & \\
\hline Olive oil industry & $\begin{array}{c}\text { Electro-chemical } \\
\text { Anode: Ti/Pt, } \\
\text { Cathode: SS } 304\end{array}$ & $1(60)$ & 1.3 & COD (41\%) & (Vlyssides et al., 1999) \\
\hline Olive oil industry & $\begin{array}{l}\text { Electro-chemical } \\
\text { Anode: Ti/Pt, } \\
\text { Cathode: SS } 304\end{array}$ & $10(600)$ & 12.3 & COD (93\%) & (Israilides et al., 1997) \\
\hline
\end{tabular}

In this study, EF trials at different $\mathrm{H}_{2} \mathrm{O}_{2}$ doses such as $313,626,940$, and $1253 \mathrm{mg} \mathrm{l}^{-1}$ corresponding to $25 \%, 50 \%, 75 \%, 100 \%$ of theoretical $\mathrm{H}_{2} \mathrm{O}_{2}$ dose, respectively were performed using $24.0 \mathrm{~W}, 31.0 \mathrm{~V}, 0.75 \mathrm{~A}$ of electrical power. As can be seen from Equation-8, required theoretical $\mathrm{H}_{2} \mathrm{O}_{2}$ dose for removing all COD compounds is equal to $1253 \mathrm{mg} \mathrm{l}^{-1}$. Iron electrode, which was used during the electrolytic processes, increased the concentration of $\mathrm{Fe}^{2+}$ ions in electrolyte with increasing reaction time. The $\mathrm{Fe}^{2+}$ 
ions diffuse from iron anode and catalyze the formation of hydroxyl radicals $(\bullet \mathrm{OH})$ in Fenton reaction which can be seen from equation 1. In EF and electro-coagulation (EC) processes, the amount of electrical energy required for the treatment of a wastewater depends on desired treatment efficiency and wastewater characteristics such as organic loading, $\mathrm{pH}$, turbidity etc. Some data from literature on the unit energy demand for pollutant removal in wastewater treatment were given in Table 1. From these studies it appears that prolonged times such as hours are required to attain high treatment efficiencies.

\section{Materials and methods}

Wastewater samples were taken from a treatment plant of a Textile industry. COD and conductivity of the wastewater were $590 \mathrm{mg} \mathrm{l}^{-1}$ and $2.3 \mathrm{mS} \mathrm{cm}^{-1}$ (at $20^{\circ} \mathrm{C}$ ), respectively. According to guidelines for industrial wastewater discharge in study area, effluent pollution of treated wastewater for textile factory has to be $200 \mathrm{mg} \mathrm{COD}^{-1}$. The treatment plant includes an equalization basin which collects wastewaters from small process units in the textile industry. The sample was put into PE containers and taken to the laboratory and protected at $+4{ }^{\circ} \mathrm{C}$ prior to performing the experiments. The experimental set-up used in the study is presented in Figure 1.

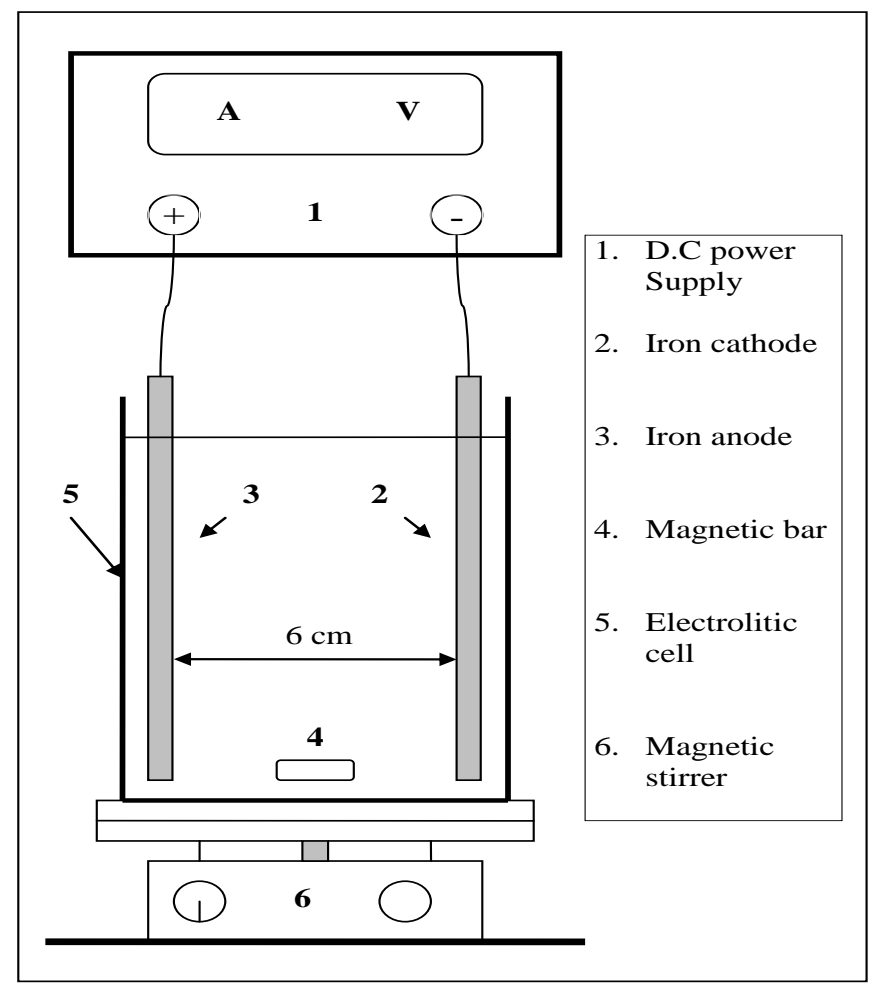

Figure 1. Experimental Set-up

Experimental studies were performed in a 0.5 I glass-made batch reactor, equipped with a cathode and anode, both of which made of iron and installed in parallel. Distance between the electrodes was $6.0 \mathrm{~cm}$ (dimensions of electrodes were $2.0 \mathrm{~mm} \times 6.2 \mathrm{~cm} \times 7.4 \mathrm{~cm}$ ). Electrodes were plunged into the beaker containing $0.4 \mathrm{I}$ of samples of textile wastewater. The total effective electrode area was $46.0 \mathrm{~cm}^{2}$.

The electrodes were connected to a Good Will GPC 3030D model digital DC power supply. All the runs were performed at initial temperature of $20^{\circ} \mathrm{C}$. $\mathrm{pH}$, temperature and conductivity measurements were performed by a $\mathrm{HACH}$-Lange $\mathrm{HQ} 40 \mathrm{D}$ model $\mathrm{pH}$ meter. A sample of $0.4 \mathrm{I}$ of wastewater was first placed into the electrochemical cell, and subsequently $\mathrm{pH}$ was adjusted to 3 with $1 \mathrm{~N}_{2} \mathrm{SO}_{4}$. After that, $\mathrm{H}_{2} \mathrm{O}_{2}$ was added in appropriate amounts to come up with initial concentrations of 313,626 , 940, or 
$1253 \mathrm{mg} \mathrm{l}^{-1}$. The current density was adjusted to a desired value, and then electrolysis was started and kept on till all $\mathrm{H}_{2} \mathrm{O}_{2}$ was consumed up.

The analysis of $\mathrm{H}_{2} \mathrm{O}_{2}$ was done by the permanganometric method (www.h2o2.com). During each EF trial, samples were taken at appropriate intervals, and then left settling for $30 \mathrm{~min}$. In the study, all analyses were carried out on treated samples taken out the limpid phase of the beaker. All chemicals (Merck) used in this study were in analytical grade. All chemical analyses used in this work were carried out in accordance with the Standard Methods for Examination of Water and Wastewater (APHA, 1998). Closed reflux titrimetric method was used for COD analysis and HACH-Lange DRB 200 model thermoreactor was used as a digester. Furthermore, HACH-Lange DR 5000 model spektrofotometer was used to determine absorbance values of the samples.

It is known that treatment cost is important factor for treatment processes. So, treatment cost per $\mathrm{kg}$ COD removal was estimated via oxidant doses and given as unit energy demand (UED). UED of the EF process was calculated from equation 9 (Apaydin et al., 2009).

$\mathrm{UED}_{(\mathrm{t})}=\frac{[\mathrm{A} \times \mathrm{V} \times \mathrm{t}]}{\left[10 \times \mathrm{C}_{\mathrm{i}} \times \mathrm{n}(\mathrm{t})\right]}$

Where UED for each $\mathrm{m}^{3}$ wastewater is the unit energy demand $\left(\mathrm{kWh} \mathrm{kg}^{-1} \mathrm{COD}^{-1}\right.$ removed $\left.^{-1}\right) ; \mathrm{C}_{\mathrm{i}}$ is beginning COD concentration, $\mathrm{kg} \mathrm{m}^{-3}, \mathrm{n}$ is COD removal efficiency (\%), $\mathrm{t}$ is reaction time, hour, $\mathrm{A}$ is the total current applied, Ampere, and $\mathrm{V}$ is the overall cell voltage, Volt.

\section{Results and discussion}

The EF treatments were performed using different oxidation doses and constant electrical power of 24 W. Results have demonstrated that wastewater began to become clear in the reaction beaker and ultimately appear totally visible after 2 min from the start of the reaction. It was also observed that the volume of the precipitating mud increased with the presence ferrous irons in the solution. Amounts of residual $\mathrm{H}_{2} \mathrm{O}_{2}$ were presented in Figure 2 via reaction time. COD removals based on $\mathrm{H}_{2} \mathrm{O}_{2}$ doses were presented at Figure 3 via reaction time.

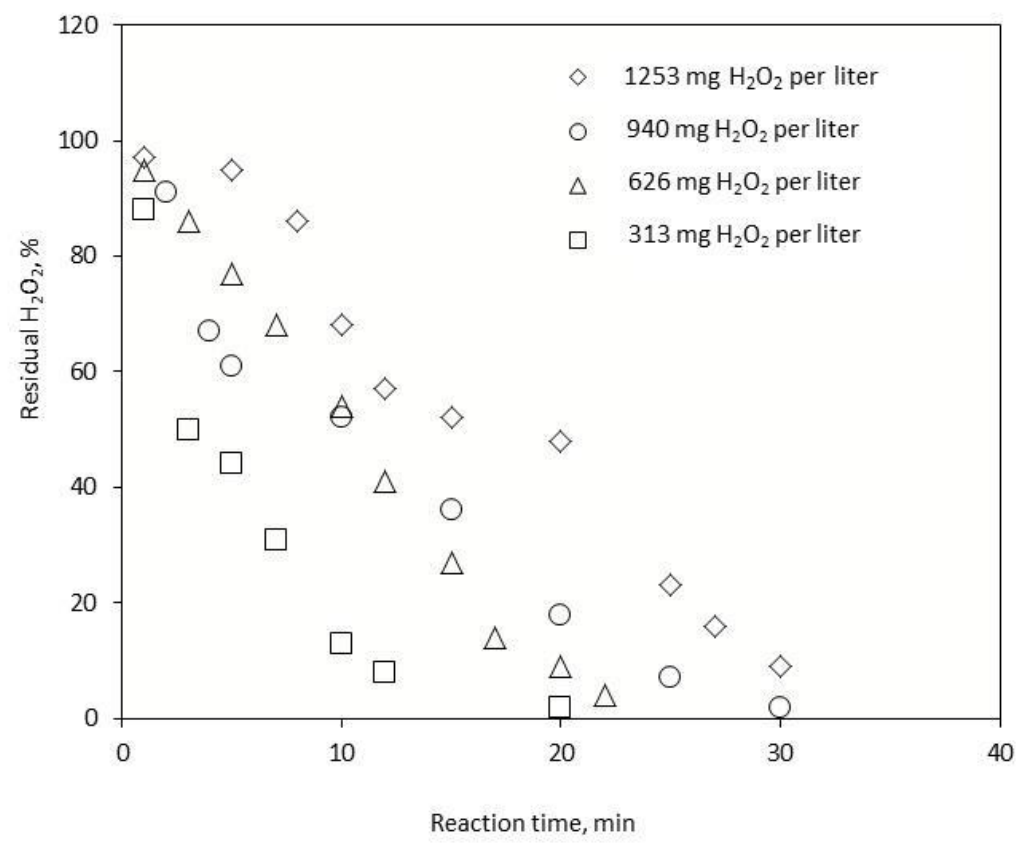

Figure 2. Residual $\mathrm{H}_{2} \mathrm{O}_{2}$ for different oxidant doses via reaction time. 
As can be seen from Figure 2, residual $\mathrm{H}_{2} \mathrm{O}_{2}$ decreases with reaction time. It might be recalled that, for the EF application to take place, the presence of residual oxidant and adequate catalyst (Ferrous ions) concentration are essential. Otherwise, undesirable reactions through equations $[3,4$ and 5$]$ could occur resulting with a decrease in the treatment efficiency.

It is observed from Figure 3 that, in the case of the presence of $1253 \mathrm{mg} \mathrm{H}_{2} \mathrm{O}_{2} \mathrm{I}^{-1}$ (100\% theoretical dose) and the application of electrical power of $24.0 \mathrm{~W}$, the removal of COD was around $75 \%, 67 \%$, and $25 \%$ after 30,20, and 10 min of reaction period, respectively. In the case of the presence of $940 \mathrm{mg} \mathrm{H}_{2} \mathrm{O}_{2} \mathrm{~L}^{-1}$ ( $75 \%$ theoretical dose) and the application of electrical power of $24.0 \mathrm{~W}$, about $73 \%, 55 \%$, and $40 \%$ of COD removals were attained within 30, 20, and $10 \mathrm{~min}$ of reaction time. Using $626 \mathrm{mg} \mathrm{H}_{2} \mathrm{O}_{2} \mathrm{I}^{1}(50 \%$ theoretical dose) and the electrical power of $24.0 \mathrm{~W}$, the removal of COD was $79 \%$ in $30 \mathrm{~min}, 60 \%$ in 20 min and $50 \%$ in $10 \mathrm{~min}$. Finally, in the case of the presence of $313 \mathrm{mg} \mathrm{H}_{2} \mathrm{O}_{2} \mathrm{I}^{-1}$ (25\% theoretical dose) and the use of similar electrical power, the removal of COD was $99 \%$ in $30 \mathrm{~min}, 99 \%$ in $20 \mathrm{~min}$ and $86 \%$ in 10 min. According to these experimental results, the optimum dose for $\mathrm{H}_{2} \mathrm{O}_{2}$ seems to be $313 \mathrm{mg} \mathrm{l}^{-1}$, which was, in fact the lowest dose used in the experiments. It appears that $\mathrm{H}_{2} \mathrm{O}_{2}$ concentrations above $313 \mathrm{mg} \mathrm{I}^{-1}$ hamper the formation of hydroxyl free radicals, which in turn lowers the COD removal efficiency by the EF treatment. It is also important to note that the chemical and energy consumption rates can be significantly minimized with reducing the dose and treatment time, which was actually the case at $313 \mathrm{mg} \mathrm{l}^{-1}$ of $\mathrm{H}_{2} \mathrm{O}_{2}$ where more than $85 \%$ of COD reduction was achieved within just 10 min of reaction time.

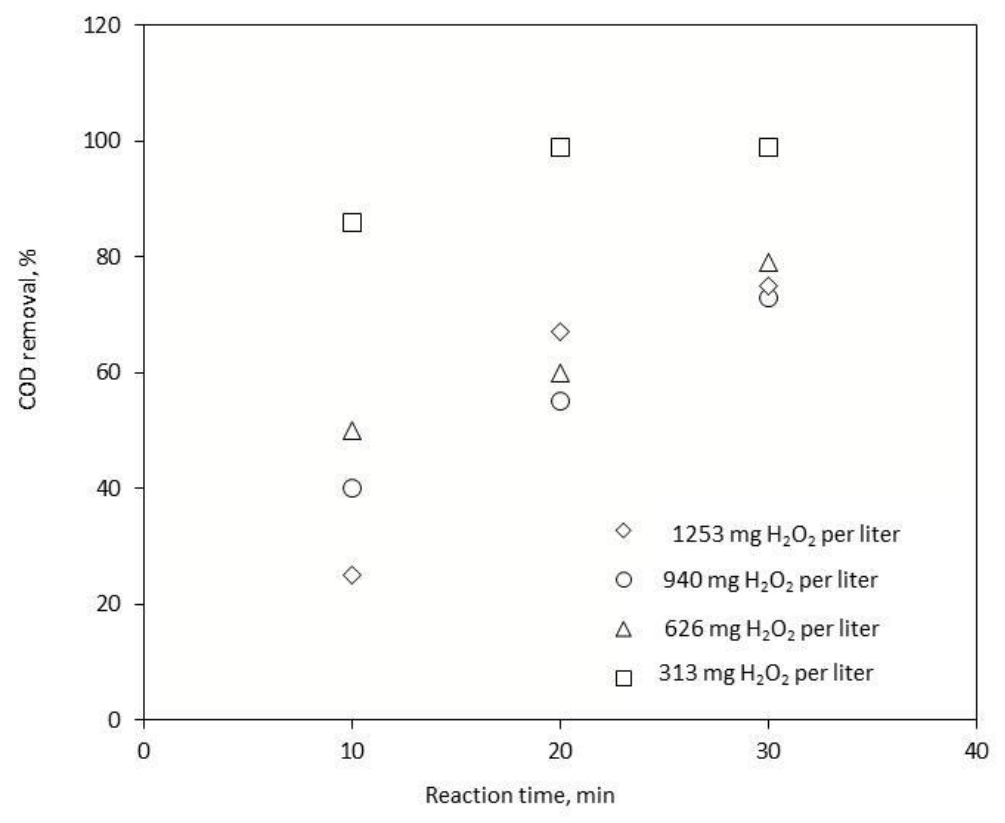

Figure 3. COD removal via reaction time during EF process.

In the presence of $\mathrm{H}_{2} \mathrm{O}_{2}$; dissolved ferrous ion $\left(\mathrm{Fe}^{2+}\right)$, which originates from anode, is converted to the ferric ion $\left(\mathrm{Fe}^{3+}\right)$. Ferric ion is a coagulation material and forms the sludge with $\mathrm{Fe}(\mathrm{OH})_{3}$. In the case of maximum COD removal efficiency of $86 \%$ obtained from $313 \mathrm{mg} \mathrm{H}_{2} \mathrm{O}_{2} \mathrm{I}^{-1}$ dose (10 min, 24.0 Watt), the energy consumption was calculated as $0.008 \mathrm{kWh} \mathrm{kg}^{-1} \mathrm{COD}^{-1}$ removed ${ }^{-1}$ based on Equation 9.

Color and turbidity are two of the physical parameters in wastewater treatment processes. Absorbance values at specific wave length of visible light are important to determine treatment efficiency of wastewater. Absorbance values with different wave lights at EF process were determined using a spectrophotometer, having $10-\mathrm{mm}$ absorption cells and an effective operating range from 400 to 700 
$\mathrm{nm}$. Results obtained from the analysis were given at Figure 4 based on reaction time and oxidant doses. According to Figure 4, absorbance values in different wave lengths $(436,525,620$, and $700 \mathrm{~nm})$ obtained from EF processes are lower than absorbance values of original textile samples. The lowest absorbance values were obtained at the highest $\mathrm{H}_{2} \mathrm{O}_{2}$ doses, used in the experiments.

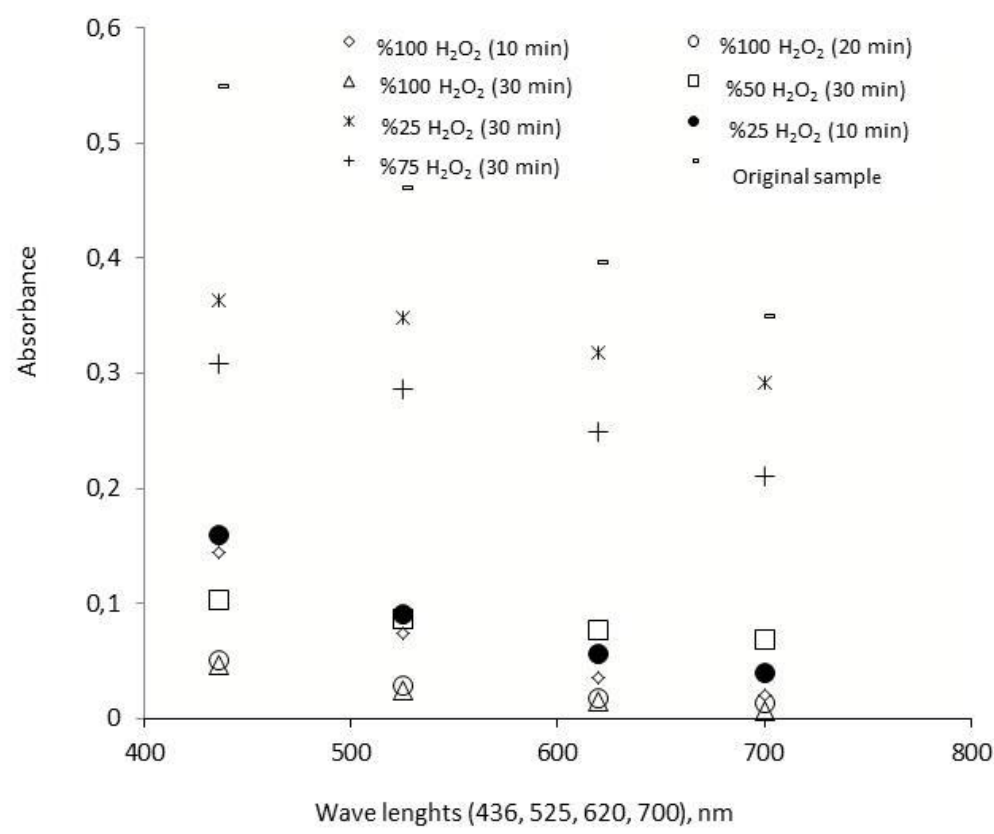

Figure 4. Absorbance values for the samples obtained in the study

Experimental results in Figure 4 show that absorbance value is decreased by $80 \%$ using $100 \% \mathrm{H}_{2} \mathrm{O}_{2}$ theoretical dose during 20 min of reaction time. Moreover, both $100 \% \mathrm{H}_{2} \mathrm{O}_{2}$ theoretical dose during 20 min and $50 \% \mathrm{H}_{2} \mathrm{O}_{2}$ theoretical dose during $30 \mathrm{~min}$ of reaction time, absorbance values were found to be similar. But, the reaction time of the latter was longer than that of the former. Therefore, the former seems to be more cost effective in terms of energy consumption, while the latter is favorable because of requiring lower chemical doses.

According to results obtained from the studies, optimum requirements to supply to guidelines for industrial wastewater discharge in study area are:

1) $1253 \mathrm{mg} \mathrm{H}_{2} \mathrm{O}_{2} \mathrm{I}^{-1}$ dose and 20 min reaction time (effluent $\mathrm{COD}=195 \mathrm{mg} \mathrm{l}^{-1}$ ) or $30 \mathrm{~min}$ reaction time (effluent $\mathrm{COD}=147 \mathrm{mg} \mathrm{l}^{-1}$ ).

2) $940 \mathrm{mg} \mathrm{H}_{2} \mathrm{O}_{2} \mathrm{I}^{-1}$ dose and 30 min reaction time (effluent $\mathrm{COD}=160 \mathrm{mg} \mathrm{I}^{-1}$ ).

3) $626 \mathrm{mg} \mathrm{H}_{2} \mathrm{O}_{2} \mathrm{I}^{-1}$ dose and 30 min reaction time (effluent $\mathrm{COD}=124 \mathrm{mg} \mathrm{I}^{-1}$ ).

4) $313 \mathrm{mg} \mathrm{H}_{2} \mathrm{O}_{2} \mathrm{I}^{-1}$ dose and 10 min reaction time (effluent $\mathrm{COD}=83 \mathrm{mg} \mathrm{l}^{-1}$ ) or $20 \mathrm{~min}$ reaction time (effluent COD $=6 \mathrm{mg} \mathrm{I}^{-1}$ ).

EF treatability studies gave the best results for $313 \mathrm{mg} \mathrm{H}_{2} \mathrm{O}_{2} \mathrm{I}^{-1}$ (10 min reaction time). The dose supplies both minimum $\mathrm{H}_{2} \mathrm{O}_{2}$ dose and requires lowest energy consumption as $0.008 \mathrm{kWh} \mathrm{kg}^{-1} \mathrm{COD}^{-1}$ removed for treating textile wastewater.

\section{Conclusions}

The electro-fenton (EF) treatment was found to be effective in removing the COD of textile wastewater. The major reaction mechanisms in the $\mathrm{EF}$ process include coagulation and hydroxyl free radical oxidation. While the coagulation occurred directly with ferrous ions, the hydroxyl free radical oxidation 
was achieved based on the reaction between hydrogen peroxide and $\mathrm{Fe}^{2+}$ ions. According to the previous studies, the efficiency of COD reduction ranges from 41 to $99 \%$ depending on several variables such as wastewater type, energy consumption, reaction time, or $\mathrm{pH}$. In our study, the overall COD removal efficiencies were found to be between $65 \%$ and $99 \%$ with respect to the amount of $\mathrm{H}_{2} \mathrm{O}_{2}$ used in the experiments. The lower the dose of hydrogen peroxide, the higher the removal efficiency obtained by the EF treatment. About more than 85\% COD reduction was attained within 10 min when the oxidant dose was adjusted to $313 \mathrm{mg} \mathrm{I}^{-1}$, recorded as the optimum dose for the electro-fenton treatment of the textile wastewater. Hence, EF process can be used as a suitable alternative treatment for the textile wastewaters.

\section{References}

Apaydin Ö., Kurt U. and Gönüllü M.T. (2009), An Investigation on The Treatment of Tannery Wastewater by Electrocoagulation, Global Nest Journal, 11, 546-555.

APHA (1998), Standard Methods for the Examination of Water and Wastewater, Twentieth Edition, American Public Health Association, Washington DC.

Arapoglou D., Vlyssides A., Israilides C., Zorpas A. and Karlis P. (2003), Detoxification of methyl-parathion pesticide in aqueous solutions by electrochemical oxidation, Journal of Hazardous Materials, B98, 191-199.

Chen X., Chen G. and Yue P.L. (2003), Anodic oxidation of dyes at novel Ti/B-diamond electrodes, Chemical Engineering Science, 58, 995-1001.

Daneshvar N., Oladegaragoze A. and Djafarzadeh N. (2006), Decolorization of basic dye solutions by electrocoagulation: An investigation of the effect of operational parameters, Journal of Hazardous Materials, 129, 116-122.

Golder A.K., Hridaya N., Samanta A.N. and Ray S. (2005), Electrocoagulation of methylene blue and eosin yellowish using mild steel electrodes, Journal of Hazardous Materials, B127, 134-140.

Israilides C.J., Vlyssides A.G., Mourafeti V.N. and Karvouni G. (1997), Olive oil wastewater treatment with the use of an electrolysis system, Bioresource Technology, 61 163-170.

Kurt U., Apaydin Ö. and Gonullu M.T. (2007), Reduction of COD in wastewater from an organized tannery industrial region by electro-Fenton process, Journal of Hazardous Materials, 143, 33-40.

Parsons S. (2004), Advanced oxidation processes for water and wastewater treatment, IWA Publishing, London UK.

Pignatello J.J., Oliveros E. and MacKay A. (2006), Advanced oxidation processes for organic contaminant destruction based on the Fenton reaction and related chemistry, Critical Reviews in Environmental Science and Technology, 36, 1-84.

Vlyssides A.G., Karlis P.K., Rori N. and Zorpas A.A. (2002), Electrochemical treatment in relation to pH of domestic wastewater using Ti/Pt electrodes, Journal of Hazardous Materials, B95, 215-226.

Vlyssides A.G., Karlis P.K. and Zorpas A.A. (1999), Electrochemical oxidation of noncyanide strippers wastes, Environmental International, 25, 663-670.

www.h202.com/technical-library/analytical-methods/default.aspx?pid=68\&name=Permanganate-Titration

Yavuz Y. and Koparal A.S. (2006), Electrochemical oxidation of phenol in a parallel plate reactor using ruthenium mixed metal oxide electrode, Journal of Hazardous Materials, 136, 296-302. 